\title{
Role of the Serotonergic System in the Pathogenesis of Major Depression and Suicidal Behavior
}

\author{
J. John Mann, M.D.
}

Phylogenetically, the serotonergic system is one of the oldest transmitter systems in the brain. Combining a complex and widespread innervation of most cortical and subcortical structures, with over a dozen receptor subtypes, there is a diversity of signaling opportunities and functional roles that explain the association of serotonin with many different types of psychopathological conditions. The role of the serotonergic system in mood disorders and in the predisposition for suicidal behavior are reviewed in this paper. Effects on the serotonergic system underlie the antidepressant action of many types of medications and must be integrated into a neurobiological model of mood disorders. [Neuropsychopharmacology 21:99S-105S, 1999] (C) 1999 American College of Neuropsychopharmacology. Published by Elsevier Science Inc.
KEY WORDS: Depression; Serotonin; Trait; Postmortem; Brain; Functional brain imaging; Cerebrospinal fluid; Neuroendocrine; Platelet; Antidepressant treatment

In 1948, a serum tonic factor released from platelets during blood clotting was first isolated, purified, and identified as a monoamine named serotonin by Rapport, Green, and Page (Rapport et al. 1948). This is of personal relevance, because Dr. Maurice Rapport was the first Chief of the Department of Neuroscience at New York State Psychiatric Institute, and I have the honor of being the third Chief of Neuroscience at New York State Psychiatric Institute. A strong tradition of serotonin research in this Department has been uninterrupted since the foundation of this department (Kolb and Roizin 1993). As described elsewhere in this volume, serotonin was subsequently found to be the same

From the Department of Neuroscience, New York State Psychiatric Institute, Department of Psychiatry, Columbia University College of Physicians \& Surgeons, New York, NY, USA.

Address correspondence to: J. John Mann, M.D., Department of Neuroscience, New York State Psychiatric Institute, 1051 Riverside Drive, Box 42, New York, NY 10032, USA.

Received October 17, 1998; revised March 5, 1999; accepted March 26, 1999. as enteramine, an amine found in the small intestine and, subsequently, the highest concentrations of serotonin were found to be in the brainstem, with lesser concentrations throughout the brain. It became clear that serotonin was really a neurotransmitter, in addition to playing a role in intestinal motility and platelet aggregation.

In 1969, several investigators proposed the indoleamine hypothesis of depression (Coppen 1969; Lapin and Oxenkrug 1969; Coppen et al. 1972; Charney et al. 1981; Meltzer and Lowy 1987). This hypothesis proposed that the vulnerability to either depression or mania was related to decreased serotonergic activity, attributable to either less serotonin release or to fewer serotonin receptors or impaired serotonin receptormediated signal transduction. Over the last 30 years, a variety of studies of the serotonergic system have reinforced its role in major depression and identified additional associations with suicidal behavior, impulsive aggression, eating disorders, obsessive-compulsive disorder, anxiety disorders, and alcoholism. The serotonergic system also plays a role in the regulation of a variety of basic biological functions including sleep, appetite, circadian rhythm, and cognitive function. 


\section{NEUROANATOMY OF THE SEROTONERGIC SYSTEM}

The neuroanatomy of the serotonergic system in the human brain has been well described by Törk (1990). The reader is directed to that paper for its excellent figures. The largest nucleus, the dorsal raphe, is divided into five or six subgroups, depending upon the histological methods employed. There are other major nuclei, including the median raphe nucleus, which projects to all parts of the brain. Two major ascending systems are described. One involves thin axons, which are the most numerous, have varicosities that are fusiform in shape, and are sometimes known as D fibers. The second system has thicker fibers with fewer varicosities, known as $\mathrm{M}$ fibers. There are also very fine fibers with large, round or oval varicosities. The $\mathrm{M}$ fibers and the $\mathrm{D}$ fibers provide a dual system of innervation, and the $\mathrm{M}$ fiber system includes basket axons that envelop target neurons in the cortex. This extensive system of innervation by the serotonergic system of cortical and subcortical target areas permits the serotonergic system to affect many brain functions and provides the anatomical basis for explaining how serotonin can influence so many diverse brain functions. At the same time, it also provides an anatomical basis for the role identified for the serotonergic system in many psychiatric disorders. Within the raphe nuclei, subgroups of serotonergic neurons have co-transmitters or peptides, including substance $\mathrm{P}$ and thyrotropin-releasing hormone. The role of substance $\mathrm{P}$ in the serotonergic system is of particular interest, given recent evidence that substance $\mathrm{P}$ antagonists may have antidepressant properties (Kramer et al. 1998).

\section{SEROTONIN RECEPTOR SUBTYPES}

The serotonergic system has over a dozen serotonin receptor subtypes (Saudou and Hen 1994). The basis of the classification of these receptor subtypes depends upon a number of criteria, including genetic, the transducer to which the receptors are coupled, and pharmacological properties. Not all of these receptor subtypes have identified physiological roles in the brain, and selective agonists and antagonists have not been identified for all the receptor subtypes. Nevertheless, the existence of so many receptor subtypes for a single transmitter permits a great diversity of signaling so that the same neurotransmitter can produce very different effects on different neurons and on different parts of the same neuron. A discussion of the various subtypes of these receptors is beyond the scope of this paper, but those receptor subtypes that have been particularly involved in the pathogenesis of depression and in suicide are discussed.

\section{5-HT ${ }_{1 \mathrm{~A}}$ Receptors}

The $5-\mathrm{HT}_{1 \mathrm{~A}}$ receptor has been hypothesized to have a role in depression and anxiety based on evidence that $5-\mathrm{HT}_{1 \mathrm{~A}}$ agonists may have anxiolytic and antidepressant properties (Baldwin and Rudge 1995). $5-\mathrm{HT}_{1 \mathrm{~A}}$ receptors exist as autoreceptors on the soma and dendrites of serotonergic neurons (Sotelo et al. 1990); whereas, they are largely postsynaptic receptors in the serotonin system's terminal fields, on target neurons in the cortex and subcortical regions (Pazos et al. 1987). Thus, reduced function of $5-\mathrm{HT}_{1 \mathrm{~A}}$ autoreceptors would result in increased serotonin transmission; whereas, decreased function at the target neurons would result in decreased $5-\mathrm{HT}_{1 \mathrm{~A}}$-mediated neurotransmission effects (Blier et al. 1990). This has led to a number of hypotheses with regard to the action of antidepressants and drugs effective for obsessive-compulsive disorder. Blier and colleagues have reported that chronic treatment with antidepressants produces a reduction in electrophysiological responsivity of the somatodendritic $5-\mathrm{HT}_{1 \mathrm{~A}}$ autoreceptor and no reduction in $5-\mathrm{HT}_{1 \mathrm{~A}}$ receptor responses in the hippocampus (Blier et al. 1990). They propose that the progressive desensitization of the autoreceptor leads to a progressive increase in serotonin activity and, thereby, mediates an antidepressant effect. Autoradiography studies have suggested that there may be downregulation of somatodendritic autoreceptors and no effect on hippocampal postsynaptic $5-\mathrm{HT}_{1 \mathrm{~A}}$ receptors with chronic antidepressant administration. Interestingly, electroconvulsive shock (ECS) produces an increase in $5-\mathrm{HT}_{1 \mathrm{~A}}$ receptors in parts of the hippocampus (Hayakawa et al. 1994), and, thereby, may mediate an antidepressant effect. 5- $\mathrm{HT}_{1 \mathrm{~A}}$ receptor responses in orbital prefrontal cortex are reported to be decreased by selective serotonin reuptake inhibitors (SSRIs) with long-term administration in rodents, and Blier and colleagues have proposed that this is the mechanism of action that underlies the therapeutic effect of SSRIs in Obsessive-compulsive disorder (see elsewhere in this volume).

\section{5-HT $1 \mathrm{~B}$ Receptors}

The 5- $\mathrm{HT}_{1 \mathrm{~B}}$ receptor is reported to have a role in the regulation of impulsive-aggressive and sexual behaviors, cocaine intake, and alcohol intake, based on the observation of an increase in all of these behaviors in $5-\mathrm{HT}_{1 \mathrm{~B}}$ knockout mice (Saudou et al. 1994; Ramboz et al. 1996; Rocha et al. 1997). Very few studies have been carried out of $5-\mathrm{HT}_{1 \mathrm{~B}}$ receptors in humans, and the development of therapeutic tools that affect this receptor type is in progress. The $5-\mathrm{HT}_{1 \mathrm{~B}}$ receptor is very closely related to the $5-\mathrm{HT}_{1 \mathrm{D}}$ receptor. $5-\mathrm{HT}_{1 \mathrm{D}}$ receptor agonists have been successfully used in the treatment of migraine (Perry and Markham 1998). Sumatriptan, a 5-HT $1 \mathrm{D}$ agonist, presumably activates $5-\mathrm{HT}_{1 \mathrm{D}}$ autoreceptors at sero- 
tonin nerve terminals, reducing serotonin release, and this may account for its antimigrainous action. $5-\mathrm{HT}_{1 \mathrm{D}}$ receptors function as autoreceptors both at the level of the nerve terminals as well as autoreceptors on the soma of serotonin neurons. The augmentation or acceleration of antidepressant effects is being proposed for drugs such as pindolol, which are $5-\mathrm{HT}_{1 \mathrm{~A}}$ autoreceptor antagonists. $5-\mathrm{HT}_{1 \mathrm{D}}$ antagonists are another class of potential augmentators of antidepressant action.

\section{5- $\mathrm{HT}_{2 \mathrm{~A}}$ Receptors}

A role for the 5- $\mathrm{HT}_{2 \mathrm{~A}}$ receptor has been proposed in the pathogenesis of major depression. Some studies have suggested that tricyclic antidepressants may downregulate the number of $5-\mathrm{HT}_{2 \mathrm{~A}}$ receptors in rat cerebral cortex, and a course of ECS in rodents has been reported to increase the number of $5-\mathrm{HT}_{2 \mathrm{~A}}$ receptors. This effect of ECS may be a mechanism for enhancing $5-\mathrm{HT}_{2 \mathrm{~A}}$ receptor-mediated signaling in the brain and has, therefore, been proposed as a mechanism of antidepressant action of electroconvulsive therapy (Mann 1998a). Whether this effect actually occurs in human brain is unknown and we will have to await the conduct of neuroreceptor studies using such techniques as positron emission tomography (PET) or single-photon emission computer tomography (SPECT). Of note, some studies have reported higher levels of $5-\mathrm{HT}_{2 \mathrm{~A}}$ receptors in the brain of suicides and on the platelets of individuals with major depression who have attempted suicide (see Mann 1998b for a review). Thus, there is an association between increased numbers of $5-\mathrm{HT}_{2 \mathrm{~A}}$ receptors and suicidal behavior, but the implications of the increase in receptor number is uncertain. Lesioning the serotonergic system in rodents does not produce a consistent upregulation of $5-\mathrm{HT}_{2 \mathrm{~A}}$ receptors and, therefore, it is not certain that the increased number of such receptors reflects reduced serotonin release. Our group (Mann et al. $1992 \mathrm{~b}$ ) found that the increased number of platelet $5-\mathrm{HT}_{2 \mathrm{~A}}$ receptors was actually associated with decreased signal transduction in platelets of depressed patients with a history of suicidal behavior. Thus, it remains to be determined whether the increased number of $5-\mathrm{HT}_{2 \mathrm{~A}}$ receptors in the prefrontal cortex of suicides is, in fact, offset by impaired signal transduction, or perhaps is secondary to signal transduction defects downstream from the receptor.

\section{5-HT ${ }_{3}$ Receptors}

The $5-\mathrm{HT}_{3}$ receptor subgroup, originally identified as the " $\mathrm{M}$ " receptors by Gaddum and Picarelli (1957), is found in many peripheral tissues. Within the CNS, this subpopulation has been shown to regulate the release of dopamine from rat striatal slices (Costall et al. 1987; Bladina et al. 1988) and the release of acetylcholine. $5-\mathrm{HT}_{3}$ antagonists, such as ondansetron, are valuable in controlling nausea associated with chemotherapy $(\mathrm{Cu}-$ beddu et al. 1990), and the $5-\mathrm{HT}_{3}$ receptor population is concentrated in relation to the nucleus of the tractus solitarius and the emetic center in the brainstem. $5-\mathrm{HT}_{3}$ receptors are distinguished from other serotonin receptors in that they are an ion channel ligated receptor (Costall 1993). Preliminary studies have not linked this receptor population to mood disorders or suicidal behavior.

\section{SEROTONERGIC SYSTEM AND MAJOR DEPRESSION}

Reduced serotonergic function has been related to the syndrome of a major depressive disorder and, in addition, to the components of psychopathology, as discussed above. The methods for characterizing serotonergic function and measuring it are mostly limited to cerebrospinal fluid, neuroendocrine challenge tests, platelet serotonin protein related assays, and functional brain imaging of the serotonergic system.

\section{Cerebrospinal Fluid 5-Hydroxyindoleacetic Acid in Depression}

Some of the earliest studies of the serotonergic system in the brain of patients employed the method of assaying the breakdown product of serotonin, 5-hydroxyindoleacetic acid (5-HIAA) (Mann et al. 1989). The underlying assumption is that 5-HIAA is related to neuronal activity. Several studies, but not all, have found reduced levels of CSF 5-HIAA in depressed patients (Dencker et al. 1966; Mendels et al. 1972; van Praag and de Haan 1979; Åsberg et al. 1984; Mårtensson et al. 1989). The degree of reduction of CSF 5-HIAA generally does not correlate with severity of depression. Many antidepressant medications, particularly serotonin reuptake inhibitors and monoamine oxidase inhibitors (MAOIs), reduce CSF 5-HIAA (Mårtensson et al. 1989) because of feedback inhibition resulting from increased intrasynaptic concentrations of serotonin. Thus, low levels of CSF 5-HIAA in treated patients do not indicate reduced serotonergic activity. Levels of CSF 5-HIAA are lower in depressed patients with a history of serious suicidal behavior, as compared to depressed patients with no history of suicide attempts (see Mann et al. 1996b for a review). Gibbons and Davis (1986) analyzed CSF 5-HIAA data in depressed patients from five research groups and found that the levels had a bimodal distribution. The low CSF 5-HIAA group were not distinguished by more severe depression, but by a history of serious suicide attempts. Given that CSF 5-HIAA correlates with levels of 5-HIAA in prefrontal cortex in postmortem studies, it has been proposed that CSF 
5-HIAA is a reasonable index of prefrontal serotonin turnover.

\section{Serotonin Neuroendocrine Challenge Tests}

The most widely used challenge agent to study the serotoneric system has been fenfluramine, which causes the release of serotonin and blocks its reuptake. Serotonin, in turn, causes the release of corticotrophin-releasing hormone and an unidentified prolactin-releasing factor from the hypothalamus. These, in turn, cause the release of ACTH and prolactin from the pituitary into the bloodstream. ACTH causes the release of cortisol from the adrenal cortex into the blood. The usual indices of serotonin release are prolactin and cortisol release. The latter is complicated by the noise attributable to its marked diurnal variation. Studies with fenfluramine have been reviewed in detail elsewhere (Mann et al. 1995), but generally report a reduction in prolactin responses in depressed patients. We have found that patients who have had a past history of depression, but have been in remission for at least a year and are off psychotropic medications, have a blunted prolactin response that is comparable in degree to acutely depressed patients requiring electroconvulsive therapy (Flory et al. 1998). Thus, it seems that impaired serotonergic activity, as demonstrated by the fenfluramine challenge test, is present to a comparable degree when patients are in remission as when they are acutely depressed. We have hypothesized that impaired serotonergic function is a biochemical trait that underlies the vulnerability for recurrent episodes of major depression. Other types of neuroendocrine challenges also indicate impaired serotonergic function. For example, intravenously administered tryptophan and intravenous clomipramine also produce blunted neuroendocrine responses in depressed patients (Heninger et al. 1984; Golden et al. 1992). One exception to this pattern has been a report of increased corticol responses to 5-hydroxytryptophan (Meltzer et al. 1984). There have been a number of studies using $5-\mathrm{HT}_{1 \mathrm{~A}}$ agonists, such as ipsapirone and buspirone, as well as the $5-\mathrm{HT}_{2 \mathrm{~A} / 2 \mathrm{C}}$ agonist M-chlorophenylpiperazine. The studies that used serotonin receptor agonists have reported conflicting results, sometimes demonstrating impaired $5-\mathrm{HT}_{1 \mathrm{~A}}$ function and other studies not replicating these findings (Lesch et al. 1990).

A related approach used to study the serotonergic system involves depletion of serotonin by either inhibition of tryptophan hydroxylase with parachlorophenylalanine (PCPA) (Shopsin et al. 1976), or diet (Delgado et al. 1994) to produce acute tryptophan depletion. These studies have shown that depression recurs in a few hours after serotonin or tryptophan depletion in remitted, medication-free, depressed patients. Similarly, patients who have responded to serotonin reuptake inhib- itors have a transient return of depressed symptoms after acute serotonin or tryptophan depletion. Thus, the antidepressant action of these medications requires a continuous enhancement of serotonergic activity.

\section{Platelet Serotonin-Related Studies}

These studies have been very consistent in reporting reduced platelet serotonin uptake and less consistently reporting reduced serotonin transporter binding in medication-free, depressed patients, particularly in those with melancholia (Meltzer et al. 1981; Kaplan and Mann 1982). Other platelet indices have generated less consistent results. For example, monoamine oxidase activity has been reported to be low in bipolar patients and elevated in unipolar patients (Mann 1979), serotonin platelet content does not seem to show any consistent alteration (Mann et al. 1992a), and platelet 5- $\mathrm{HT}_{2 \mathrm{~A}}$ binding is increased, but apparently this effect is largely confined to individuals attempting suicide (McBride et al. 1994). A few studies have reported impaired serotonin 5- $\mathrm{HT}_{2 \mathrm{~A}}$ signal transduction in the platelet. The limitation of platelet studies is that they do not reflect the complex situation that may involve the same serotoninrelated proteins in the brain. Although some genetic effects may be detectable in the platelet, the local regional brain combination of primary pathogenic effects and compensatory adjustments and modulations by other neurotransmitter systems cannot be detected in the platelet.

\section{Postmortem Studies}

Postmortem studies of the serotonergic system in depressed patients have been largely confined to studies of suicide. Because there is an association of serotonergic abnormalities with suicide risk, it is difficult to determine what effects are attributable to the presence of a major depression as opposed to a vulnerability to suicidal behavior. Nevertheless, Ferrier and colleagues (Ferrier et al. 1986) reported a study in depressed patients dying from causes other than suicide and found a trend for a significant increase in $5-\mathrm{HT}_{2 \mathrm{~A}}$ receptor binding and a decrease in 5-HIAA, particularly in those patients with evidence of a major depression a month before death, as compared to controls. McKeith and colleagues (McKeith et al. 1987) replicated these findings using autoradiography, in terms of the $5-\mathrm{HT}_{2 \mathrm{~A}}$ receptor. Stockmeier and colleagues (Stockmeier et al. 1998) reported an increase in somatodendritic $5-\mathrm{HT}_{1 \mathrm{~A}}$ binding in the brainstem of suicides with major depression, but did not have a nondepressed, suicide control group to distinguish effects of suicide from those of major depression. Thus, there are data suggesting that not all of the changes reported in suicides may necessarily reflect the risk for suicide. Some of the neurochemical 
changes may, in fact, be attributable to the presence of major depression. Clearly, further studies of depressed patients dying from causes other than suicide would also be of considerable importance.

\section{Functional Brain-Imaging Studies of the Serotonergic System}

Only a few studies have used such modalities as positron emission tomography (PET) or SPECT to study the serotonergic system in depression. Ågren and colleagues (Ågren et al. 1991) have demonstrated reduced 5-hydroxytryptophan uptake in the brain of depressed patients. One study (D'haenen et al. 1992) found an increased number of ketanserin binding sites as demonstrated by ${ }^{123}$ I-ketanserin, using SPECT. We (Mann et al. 1996a) have reported a blunted regional glucose metabolic response to challenge with fenfluramine in depressed patients. Recently, Malison and colleagues have reported lower $\beta$-CIT binding sites in the brainstem of depressed patients (Malison et al. 1997). These studies avoid many of the pitfalls of postmortem studies and permit correlation with symptomatology at the time of the scan.

\section{A SEROTONIN TRAIT}

Depue and Spoont (1986) drew on animal and human data to describe a model where behavioral facilitation and inhibition systems were responsive to the serotonergic system, and the influence of the serotonergic system on these behavioral inhibition and facilitatory systems was not specific to any particular response system. This interesting formulation fits with data that we and others have reported linking serious suicidal behavior to a deficiency in the serotonergic system (see Mann $1998 \mathrm{~b}$ for a review). Serotonergic function correlates with past and future serious suicidal behavior, and we have suggested that it is related to the diathesis or propensity for suicidal acts. Similarly, studies by Virkkunen and others (Virkkunen et al. 1994; Virkkunen et al. 1995; Ebert and Ebmeier 1996) showing a relationship between past and future impulsive, violent behavior and impaired serotonergic function, indicate the serotonergic activity may also modulate the threshold for externally directed aggression. Rodent studies have demonstrated that serotonin depletion results in increased aggression, and serotonin augmentation results in decreased aggression (Mann 1995). The 5- $\mathrm{HT}_{1 \mathrm{~B}}$ knockout mouse demonstrates increased impulsive aggression and sexual behavior. Consistent with a biological trait, it has been demonstrated that genetic factors account for a significant part of the variance in serotonergic function, and early maternal deprivation resets serotonergic activity, in an enduring fashion, at a lower level
(Higley et al. 1993). This may explain why there is a link between maternal deprivation and child abuse with adult aggression and suicidal behavior. Studies of the serotonergic system in humans and nonhuman primates have demonstrated considerable stability over time in mature adults. There are correlations between CSF 5-HIAA and prolactin responses to fenfluramine with such behavioral traits as aggression and impulsivity (Brown et al. 1979; Brown et al. 1982; Coccaro et al. 1989; Coccaro et al. 1994). Thus, there is an impressive body of literature indicating that the serotonergic system is a relatively stable biochemical trait that correlates with behavioral traits, including impulsivity.

\section{CONCLUSIONS}

The history of the study of the serotonergic system in psychiatric disorders reflects our increasingly sophisticated measures and conceptualization of the relationship between neurobiology and behavior. Early studies of the serotonergic system were confined to blood and urine, and then later CSF and neuroendocrine challenges. Now there are direct studies of postmortem brain tissue and functional brain imaging studies. At another level, the serotonergic system was originally examined in relation to the syndrome of acute depression. More recently, we have recognized that this system is more of a biochemical trait and have identified its relationship to the vulnerability for recurrent depression and such traits as impulsivity. The very complexity of the serotonergic system means that it has the potential for a role in a variety of psychopathological conditions and, conversely, manipulating the serotonergic system has the potential for developing treatments for a wide range of psychopathological conditions. Thus, although a great deal of work has been done with regard to the serotonergic system, its complexity, in terms of anatomy, numbers of receptors, and its role in neurodevelopment, means that we again stand at a threshold of a new set of research opportunities.

\section{ACKNOWLEDGMENTS}

This work was supported by PHS grants MH46745, MH40695, MH40210, AA09004, The Diane Goldberg Foundation, and The Audrey Wallace Otto Fund of the St. Louis Community Foundation. The manuscript was expertly typed by Nancy Geibel.

\section{REFERENCES}

Ågren H, Reibring L, Hartvig P, Tedroff J, Bjurling P, Hörnfeldt K, Andersson Y, Lundqvist H, Långström B (1991): Low brain uptake of $\mathrm{L}-\left[{ }^{11} \mathrm{C}\right] 5$-hydroxytryptophan in 
major depression: A positron emission tomography study on patients and healthy volunteers. Acta Psychiat Scand 83:449-455

Åsberg M, Bertilsson L, Martensson B, Scalia Tomba GP, Thorén P, Träskman-Bendz L (1984): CSF monoamine metabolites in melancholia. Acta Psychiat Scand 69:201-219

Baldwin D, Rudge S (1995): The role of serotonin in depression and anxiety. Int Clin Psychopharm 9:41-45

Bladina P, Goldfarb J, Green JP (1988): Activation of a 5- $\mathrm{HT}_{3}$ receptor releases dopamine from rat striatal slice. Eur J Pharmacol 155:349-350

Blier P, De Montigny C, Chaput Y (1990): A role for the serotonin system in the mechanism of action of antidepressant treatments: Preclinical evidence. J Clin Psychiat 51(4, suppl):14-21

Brown GL, Ebert MH, Goyer PF, Jimersom DC, Klein WJ, Bunney WE, Jr., Goodwin FK (1982): Aggression, suicide, and serotonin: Relationships to CSF amine metabolites. Am J Psychiat 139:741-746

Brown GL, Goodwin FK, Ballenger JC, Goyer PF, Major LF (1979): Aggression in human correlates with cerebrospinal fluid amine metabolites. Psychiat Res 1:131-139

Charney DS, Menkes DB, Heninger GR (1981): Receptor sensitivity and the mechanism of action of antidepressant treatment. Implications for the etiology and therapy of depression. Arch Gen Psychiat 38:1160-1180

Coccaro EF, Siever LJ, Klar HM, Maurer G, Cochrane K, Cooper TB, Mohs RC, Davis KL (1989): Serotonergic studies in patients with affective and personality disorders. Arch Gen Psychiat 46:587-599

Coccaro EF, Silverman JM, Klar HM, Horvath TB, Siever LJ (1994): Familial correlates of reduced central serotonergic system function in patients with personality disorders. Arch Gen Psychiat 51:318-324

Coppen A, Prange AJ, Jr., Hill C, Whybrow PC, Noguera R (1972): Abnormalities of indoleamines in affective disorders. Arch Gen Psychiat 26:474-478

Coppen AJ (1969): Biochemical aspects of depression. Int Psychiat Clin 6:53-81

Costall B (1993): The breadth of action of the $5-\mathrm{HT}_{3}$ receptor antagonists. Int Clin Psychopharm 8:3-9

Costall B, Domeney AM, Naylor RJ, Tyers MB (1987): Effects of the $5-\mathrm{HT}_{3}$ receptor antagonist, GR38032F, on raised dopaminergic activity in the mesolimbic system of the rat and marmoset brain. Br J Pharmacol 92:881-894

Cubeddu LX, Hoffmann IS, Fuenmayor NT, Finn AL (1990): Efficacy of ondansetron (GR 38032F) and the role of serotonin in cisplatin-induced nausea and vomiting. $\mathrm{N}$ Engl J Med 322:810-816

D’haenen H, Bossuyt A, Mertens J, Bossuyt-Piron C, Gijsemans M, Kaufman L (1992): SPECT imaging of serotonin receptors in depression. Psychiat Res Neuroimag 45:227237

Delgado PL, Price LH, Miller HL, Salomon RM, Aghajanian GK, Heninger GR, Charney DS (1994): Serotonin and the neurobiology of depression: Effects of tryptophan depletion in drug-free depressed patients. Arch Gen Psychiat 51:865-874

Dencker SJ, Malm U, Roos B-E, Werdinius B (1966): Acid monoamine metabolites of cerebrospinal fluid in mental depression and mania. J Neurochem 13:1545-1548

Depue RA, Spoont MR (1986): Conceptualizing a serotonin trait. A behavioral dimension of constraint. Ann NY Acad Sci 487:47-62

Ebert D, Ebmeier KP (1996): The role of the cingulate gyrus in depression: From functional anatomy to neurochemistry. Biol Psychiat 39:1044-1050

Ferrier IN, McKeith IG, Cross AJ, Perry EK, Candy JM, Perry RH (1986): Postmortem neurochemical studies in depression. Ann NY Acad Sci 487:128-142

Flory JD, Mann JJ, Manuck SB, Muldoon MF (1998): Recovery from major depression is not associated with normalization of serotonergic function. Biol Psychiat 43:320 326

Gaddum JH, Picarelli ZP (1957): Two kinds of tryptamine receptor. Br J Pharmacol 12:323-328

Gibbons RD, Davis JM (1986): Consistent evidence for a biological subtype of depression characterized by low CSF monoamine levels. Acta Psychiat Scand 74:8-12

Golden RN, Ekstrom D, Brown TM, Ruegg R, Evans DL, Haggerty JJ, Jr., Garbutt JC, Pedersen CA, Mason GA, Browne J, Carson SW (1992): Neuroendocrine effects of intravenous clomipramine in depressed patients and healthy subjects. Am J Psychiat 149:1168-1175

Hayakawa H, Shimizu M, Nishida A, Motohashi N, Yamawaki S (1994): Increase in serotonin 1A receptors in the dentate gyrus as revealed by autoradiographic analysis following repeated electroconvulsive shock but not imipramine treatment. Neuropsychobiology 30:53-56

Heninger GR, Charney DS, Sternberg DE (1984): Serotonergic function in depression. Prolactin response to intravenous tryptophan in depressed patients and healthy subjects. Arch Gen Psychiat 41:398-402

Higley JD, Thompson WW, Champoux M, Goldman D, Hasert MF, Kraemer GW, Scanlan JM, Suomi SJ, Linnoila M (1993): Paternal and maternal genetic and environmental contributions to cerebrospinal fluid monoamine metabolites in Rhesus monkeys (Macaca mulatta). Arch Gen Psychiat 50:615-623

Kaplan RD, Mann JJ (1982): Altered platelet serotonin uptake kinetics in schizophrenia and depression. Life Sci 3:583588

Kolb LC, Roizin L (1993): The First Psychiatric Institute. How Research and Education Changed Practice. Washington DC, American Psychiatric Press, Inc

Kramer MS, Cutler N, Feighner J, Shrivastava R, Carman J, Sramek JJ, Reines SA, Liu G, Swain CJ, Wyatt-Knowles E, Hale JJ, Mills SG, MacCoss M, Harrison T, Hill RG, Hefti F, Scolnick EM, Cascieri MA, Chicchi GG, Sadowski S, Williams AR, Hewson L, Smith D, Carlson EJ, Hargreaves RJ, Rupniak NMJ (1998): Distinct mechanism for antidepressant activity by blockade of central substance P receptors. Science 281:1640-1645

Lapin IP, Oxenkrug GF (1969): Intensification of the central serotoninergic processes as a possible determinant of the thymoleptic effect. Lancet i:132-136

Lesch KP, Mayer S, Disselkamp-Tietze J, Hoh A, Wiesmann M, Osterheider M, Schulte HM (1990): 5- $\mathrm{HT}_{1 \mathrm{~A}}$ receptor responsivity in unipolar depression: Evaluation of ipsa- 
pirone-induced ACTH and cortisol secretion in patients and controls. Biol Psychiat 28:620-628

Mårtensson B, Nyberg S, Toresson G, Brodin E, Bertilsson L (1989): Fluoxetine treatment of depression. Clinical effects, drug concentrations, and monoamine metabolites and N-terminally extended substance P in cerebrospinal fluid. Acta Psychiat Scand 79:586-596

Malison RT, Pelton G, Carpenter L, Sanacora G, Haroon E, Potenza M, Berman R, Baldwin RM, Seibyl JS, Price LH, Innis RB, Charney DS (1997): Reduced midbrain serotonin transporter binding in depressed vs. healthy subjects as measured by $\left[{ }^{123} \mathrm{I}\right] \mathrm{b}-\mathrm{CIT}$ SPECT. Soc Neurosci Abstr 23:1220

Mann JJ (1979): Altered platelet monoamine oxidase activity in affective disorders. Psychol Med 9:729-736

Mann JJ (1995): Violence and aggression. In Bloom FE, Kupfer DJ (eds), Psychopharmacology: The Fourth Generation of Progress. New York, Raven Press, pp 1919-1928

Mann JJ (1998a): Neurobiological correlates of the antidepressant action of electroconvulsive therapy. J ECT 14:172-180

Mann JJ (1998b): The neurobiology of suicide. Nature Med 4:25-30

Mann JJ, Arango V, Marzuk PM, Theccanat S, Reis DJ (1989): Evidence for the 5-HT hypothesis of suicide: A review of postmortem studies. Br J Psychiat 155:7-14

Mann JJ, Malone KM, Diehl DJ, Perel J, Cooper TB, Mintun MA (1996a): Demonstration in vivo of reduced serotonin responsivity in the brain of untreated depressed patients. Am J Psychiat 153:174-182

Mann JJ, Malone KM, Sweeney JA, Brown RP, Linnoila M, Stanley B, Stanley M (1996b): Attempted suicide characteristics and cerebrospinal fluid amine metabolites in depressed inpatients. Neuropsychopharmacology 15:576586

Mann JJ, McBride PA, Anderson GM, Mieczkowski TA (1992a): Platelet and whole blood serotonin content in depressed inpatients: Correlations with acute and lifetime psychopathology. Biol Psychiat 32:243-257

Mann JJ, McBride PA, Brown RP, Linnoila M, Leon AC, DeMeo MD, Mieczkowski TA, Myers JE, Stanley M (1992b): Relationship between central and peripheral serotonin indexes in depressed and suicidal psychiatric inpatients. Arch Gen Psychiat 49:442-446

Mann JJ, McBride PA, Malone KM, DeMeo MD, Keilp J (1995): Blunted serotonergic responsivity in depressed patients. Neuropsychopharmacology 13:53-64

McBride PA, Brown RP, DeMeo M, Keilp J, Mieczkowski T, Mann JJ (1994): The relationship of platelet $5-\mathrm{HT}_{2}$ receptor indices to major depressive disorder, personality traits, and suicidal behavior. Biol Psychiat 35:295-308

McKeith IG, Marshall EF, Ferrier IN, Armstrong MM, Kennedy WN, Perry EK, Eccleston D (1987): 5-HT receptor binding in postmortem brain from patients with affective disorder. J Affect Disord 13:67-74

Meltzer HY, Arora RC, Baber R, Tricou B-J (1981): Serotonin uptake in blood platelets of psychiatric patients. Arch Gen Psychiat 38:1322-1326

Meltzer HY, Lowy MT (1987): The serotonin hypothesis of depression. In Meltzer HY (ed), Psychopharmacology: The Third Generation of Progress. New York, Raven Press, pp 513-526

Meltzer HY, Perline R, Tricou BJ, Lowy M, Robertson A (1984): Effect of 5-hydroxytryptophan on serum cortisol levels in major affective disorders. II. Relation to suicide, psychosis, and depressive symptoms. Arch Gen Psychiat 41:379-387

Mendels J, Frazer A, Fitzgerald RG, Ramsey TA, Stokes JW (1972): Biogenic amine metabolites in cerebrospinal fluid of depressed and manic patients. Science 175:1380-1382

Pazos A, Probst A, Palacios JM (1987): Serotonin receptors in the human brain-III. Autoradiographic mapping of serotonin-1 receptors. Neuroscience 21:97-122

Perry CM, Markham A (1998): Sumatriptan. An updated review of its use in migraine. Drugs 56:889-922

Ramboz S, Saudou F, Amara DA, Belzung C, Dierich A, Lemeur M, Segu L, Misslin R, Buhot M-C, Hen R (1996): Behavioral characterization of mice packing the $5-\mathrm{HT}_{1 \mathrm{~B}}$ receptor. NIDA Research Monograph 161:39-57

Rapport MM, Green AA, Page IH (1948): Crystalline serotonin. Science 108:329-330

Rocha BA, Ator R, Emmett-Oglesby MW, Hen R (1997): Intravenous cocaine self-administration in mice lacking 5-HT1B receptors. Pharmacol Biochem Behav 57:407-412

Saudou F, Amara DA, Dierich A, Lemeur M, Ramboz S, Segu L, Buhot M-C, Hen R (1994): Enhanced aggressive behavior in mice lacking $5-\mathrm{HT}_{1 \mathrm{~B}}$ receptor. Science 265:1875-1878

Saudou F, Hen R (1994): 5-Hydroxytryptamine receptor subtypes in vertebrates and invertebrates. Neurochem Int 25:503-532

Shopsin B, Friedman E, Gershon S (1976): Parachlorophenylalanine reversal of tranylcypromine effects in depressed patients. Arch Gen Psychiat 33:811-819

Sotelo C, Cholley B, El Mestikawy S, Gozlan H, Hamon M (1990): Direct immunohistochemical evidence of the existence of $5-\mathrm{HT}_{1 \mathrm{~A}}$ autoreceptors on serotoninergic neurons in the midbrain raphe nuclei. Eur J Neurosci 2:1144-1154

Stockmeier CA, Shapiro LA, Dilley GE, Kolli TM, Friedman L, Rajkowska G (1998): Increase in serotonin-1A autoreceptors in the midbrain of suicide victims with major depression-Postmortem evidence for decreased serotonin activity. J Neurosci 18:7394-7401

Törk I (1990): Anatomy of the serotonergic system. Ann NY Acad Sci 600:9-35

van Praag HM, de Haan S (1979): Central serotonin metabolism and frequency of depression. Psychiat Res 1:219-224

Virkkunen M, Goldman D, Nielsen DA, Linnoila M (1995): Low brain serotonin turnover rate (low CSF 5-HIAA) and impulsive violence. J Psychiat Neurosci 20:271-275

Virkkunen M, Rawlings R, Tokola R, Poland RE, Guidotti A, Nemeroff CB, Bissette G, Kalogeras K, Karonen S-L, Linnoila M (1994): CSF biochemistries, glucose metabolism, and diurnal activity rhythms in alcoholic, violent offenders, fire setters, and healthy volunteers. Arch Gen Psychiat 51:20-27 